\title{
LEGAL ASPECTS OF REGULATION OF TITLE UKRAINIAN PEOPLE ON THE GROUND IN PERSPECTIVE REFORMING LAND RELATIONS IN UKRAINE
}

\section{Olena Borschevska}

\section{INTRODUCTION}

The urgency of the work is due to the fact that nowadays the whole Ukrainian people are facing the urgent issue of opening the market / circulation of land. However, very little attention is paid to the exercise and protection of land ownership for the Ukrainian people and not for individual citizens of Ukraine. Due to the peculiarity of the subject of such property right, there is a need for a thorough study and determination of the possibility for the present legal regulation of the exercise of the property rights of the Ukrainian people for natural resources, in particular land.

Therefore, the purpose of this work was to investigate and highlight problematic issues in the exercise by the Ukrainian people of their property rights in general, and in particular, land.

The formulation of such a goal led to the following research objectives:

- identification of the property rights of the Ukrainian people;

- defining the concept of property rights of the Ukrainian people through the conceptual apparatus of civil legal instruments;

- applied coverage of the issues of opening the market / land circulation in the light of the exercise of land ownership by the Ukrainian people.

The object of the research is the system of legal relations that are formed in the process of exercising the property right of the Ukrainian people.

The subject of the research is the property of the Ukrainian people as the right of the community of citizens of Ukraine of all nationalities to own, use and dispose of land, its subsoil, atmospheric air, water and other natural resources within the territory of Ukraine, the natural resources of its continental shelf, exclusive (marine) economic zones, which are objects of property rights of the Ukrainian people.

The methodological basis of the study is the totality of general scientific, special scientific, as well as philosophical methods and techniques of scientific knowledge.

The research used the work of such scientists as, O.V. Dzera, I.O. Ivanov, A.V. Kovalenko, I. Kresina, N.S. Kuznetsova, V.V. Nosik, O.O. Pervomaisky, I.M. Perchekliy, M.P. Orzich, O.F. Skakun, I.V. Snicar, O. Stoyko and others. 
The regulatory framework for the study was the normative acts in force today, such as the Constitution of Ukraine of June 28, 1996 (as amended); The Land Code of Ukraine of October 25, 2001 (as amended); The Civil Code of Ukraine of January 16, 2003 (as amended); The Law of Ukraine "On the Procedure for Allocating in Land (on the Territory) Land Plots to Owners of Land Shares (share)" on the Use of Unallocated and Unclaimed Land Plots and Land Shares (share) of 5 June 2003, as amended; .The Law of Ukraine "On Amendments to Certain Legislative Acts of Ukraine on Resolving the Issue of Collective Land Ownership, Improvement of Land Use Rules in Agricultural Land, Prevention of Raiding and Encouragement of Irrigation in Ukraine". Of July 10, 2018 No. 2498-VIII; Draft Law of Ukraine "On Amendments to Certain Legislative Acts of Ukraine Concerning the Conditions of Circulation of Agricultural Lands" as amended for the second reading 03.01.2020 No. 2178-10.

Also interesting is the submission to the Constitutional Court of Ukraine of 46 People's Deputies on the interpretation of the provisions of the first sentence of part one of Article 13 and part one of Article 14 of the Basic Law, which deals with the ownership of the Ukrainian people on land.

\section{Civil Law Aspect of Determining the Legal Status of Property Rights of the Ukrainian People}

The main emphasis of almost all scholars who study the problem of property of the Ukrainian people is the conclusion that only the ecological and legal status of such property rights and, in some cases, the political context of such a legal institute. The imperfection of the legislative framework is the key to this. Thus, A. Dzera believes that the property right of the Ukrainian people is not an independent form of property and is, by its nature, state property, subject to the state of Ukraine and territorial communities, referring to Article 2 of the Civil Code of Ukraine, which reads that individuals and legal entities, as well as public entities such as the State of Ukraine, the Autonomous Republic of Crimea, territorial communities, foreign states and others, are participants in civil relations ${ }^{1}$. It is not possible to disagree with this statement, since the reference to an article of the law justifying one or another position on the basis of ownership is impossible. That is, it is impossible to justify natural law by law. Because the law must be justified by law according to the rule of law. The law should be an expression of law, but unfortunately, the legislator does not always reproduce the in-depth substance of law in legislative acts.

1 Енциклопедія цивільного права України (2009). Ін-т держави і права ім. В.М. Корецького НАН України; відповід. ред. Я.М. Шевченко. (рр. 664). Київ : Ін Юре 
Therefore, it is considered necessary to find out in what legal status the state in the person of state bodies and territorial communities in the person of bodies of local self-government realizes the property right of the Ukrainian people.

It follows from the Constitution that, the Ukrainian people, are citizens of Ukraine of all nationalities united by the legal connection of a person with the state, its affiliation with Ukraine, regardless of ethnic origin ${ }^{2}$. Thus, S.O. Komarov notes that citizenship is understood as membership of the state not as a union of all, but as a union of individuals who are in a stable, permanent, specific political and legal connection with the state. That is why it is the citizens who ensure the succession of a democratic state from generation to generation ${ }^{3}$.

In the general theoretical definition given by O.F. Skakun state is a sovereign political-territorial organization of a society with power, exercised by the state apparatus on the basis of legal norms that ensure the protection and reconciliation of public, group and individual interests with the restraint, if necessary, of legal coercion ${ }^{4}$. Society O.F. The steed calls the system of social community of people, which is created on the basis of mutual interests, mutual cooperation. It is supported by I. Kresina, O. Stoyko, arguing that the state is a collection of people who live in a certain territory organized and represented by a single authority ${ }^{5}$. But such an administrative and legal definition of the state should be harmonized with the civil law principles, since the state, according to Article 2 of the Civil Code of Ukraine, is a party to the civil legal relations. As N. Kuznetsova states, the state is not entitled to apply its own powers to legally equal subjects of these relations ${ }^{6}$, since this is contrary to the basic principle of civil law regarding equality of parties.

It follows from Article 2 of the Civil Code that territorial communities are also subject to civil law. Unfortunately, there is no clear legislative concept of the territorial community. Among scholars, the most common is the definition of territorial community M.P. Orzikh. As he considered, the social basis of self-governing territories is a territorial collective (a community, more precisely - a commune, in view of the regime of communal property in Ukraine and world experience), consisting (unlike the population of territorial units) of persons - citizens, foreigners, persons without nationals who are

${ }^{2}$ Конституція України прийнята на п’ятій сесії Верховної Ради України. (28.06.1996). Retrieved from https://zakon.rada.gov.ua/laws/show/254

${ }^{3}$ Комаров С.А. (1998) Общая теория государства и права. (рp. 81). Москва: Юрайт

${ }^{4}$ Скакун О.Ф. (2001) Теорія держави і права. Харків: Консум. Рр. 39.

${ }^{5}$ Енциклопедія цивільного права України (2009). Ін-т держави і права ім. В.М. Корецького НАН України; відповід. ред. Я.М. Шевченко. (рp. 664). Київ : Ін Юре

${ }^{6}$ Комаров С.А. (1998) Общая теория государства и права. (рр.81). Москва: Юрайт 
permanently resident or working in the territory (or who hold real estate in the territory or are taxpayers) ${ }^{7}$.

As M.V. Shulga The Ukrainian people, being the subject of property rights, refers to public entities. It is a certain community and acts as one, though it is made up of individuals and their groups ${ }^{8}$.

But for the sake of fairness and legal certainty, it should be clarified that in order to define the Ukrainian people, in the Preamble, the Ukrainian Constitutions are citizens of Ukraine of all nationalities. Therefore, the state and territorial communities, represented by state bodies and local selfgovernment bodies, should perform their functions of representation in asserting the property rights of the Ukrainian people only on behalf and, of course, in the interests of citizens of all nationalities. Here, too, there should be no opinion about the neglect of the rights of foreigners and stateless persons, since this is the exclusive property right of the Ukrainian people, which is mentioned in the Declaration on State Sovereignty of Ukraine of July 16, 1990. That is, the legislator declares to the Ukrainian people exclusive powers of exercising property rights, which, unfortunately, have not yet been given legislative consolidation.

As stipulated in Article 13 of the Constitution of Ukraine and Article 324 of the Civil Code of Ukraine, "on behalf of the Ukrainian people, the rights of the owner shall be exercised by state authorities and local self-government bodies". In this case, the state bodies and local self-government bodies perform the representative function of the state and the territorial community accordingly, which enables the state and the territorial community to dispose of the property rights of the Ukrainian people on its behalf, but it does not specify in any interests. Instead, it is interesting to draw attention to Article 326 of the Civil Code of Ukraine "State Property Law", namely to Part 2 "On behalf of and in the interests of the State, Ukraine shall exercise its right of ownership respectively by public authorities". The key phrase in this case is "in the interest". The question arises whether or not intentionally missed is a similar phrase in the article that regulates the property of the Ukrainian people.

It is known a priori that the category of "property right" belongs to the conceptual apparatus of civil, commercial law and the like. That is, private-law branches of law. It is known, and it is stated in the Constitution of Ukraine and

${ }^{7}$ Орзіх М. П.( 1995) Концепція правового статусу самоврядних територій і органів місцевого самоврядування. Місцеве та регіональне самоврядування України, № 1, 67.

${ }^{8}$ Шульга М.В, Устименко В.А. (2019) Землі як об'єкт земельних відносин: матеріали Всеукраїнської науково-практичної конференції (29 листопада 2019 р., м. Київ). Об'єкти екологічного і суміжних галузей права: теоретичні та практичні аспекти в умовах сталого розвитку. (рр.67) Київ: НАН України. Ін-т економіко-правових досліджень. 
in the Civil Code of Ukraine, that all owners are equal before the law. This also follows from the principles of civil law enshrined in Article 3 of the Civil Code of Ukraine. That is, relations of power-conquest that are inherent in the publiclaw branches of law cannot be fully transferred to relations of the exercise of property rights, since they are by their nature civil-law.

In civil law, there is a principle of equality of parties, according to which all subjects of civil law: the Ukrainian people, legal and natural persons, territorial communities and the state of Ukraine are equal and act in civil legal relations on equal terms.

Equally important is the principle of justice, which must be taken into account in relations with the Ukrainian people regarding the enjoyment of their property rights. Thus, R. Dvorkin believed that "justice is of legal importance, naturally, because of its key idea of equality. Equality can act as a right. The most fundamental of all rights is the interpretation of the right to equality in some way" "This principle of relations of the exercise of the property of the Ukrainian people by state bodies on behalf of the people of Ukraine should contain a rule regarding the consideration and interests of the Ukrainian people. This is a very important definition of civil law with regard to the provisions of representation which the state must, in essence, fulfill in exercising the property right of the Ukrainian people.

According to the doctrine of the civil law of Ukraine, the concept of ownership has a stable meaning, which does not change with the change of the subject of ownership. That is, under Article 317 of the Civil Code of Ukraine, the owner owns the rights to own, use and dispose of his property. Moreover, from the legal analysis of Article 324 of the Civil Code of Ukraine "Property of the Ukrainian People" it can be argued that the Ukrainian people are the subject of civil legal relations in the exercise of their property rights. Considering the issues in the civil law perspective, it should be noted that, of course, the Ukrainian people as a community, acting as a whole, consisting of individuals, are not able to exercise all their powers independently, since actions to exercise their owner's rights must be coordinated with each other. That is why the legislator rightly introduced the formula for which the Ukrainian people exercise their rights through the state and territorial communities in the person of state bodies and local self-government bodies. But it is not stated anywhere that the state and territorial communities can use the property of the Ukrainian people for their own benefit, that is, to exercise the property right of the Ukrainian people on behalf of the people, but not in its interests.

\footnotetext{
${ }^{9}$ Дворкін Р. (2001) Серйозний погляд на права. (pp. 12). Київ : Основи.
} 
The question arises which may be of interest to the Ukrainian people in the exercise of their property rights. Scientists believe that the interests of the Ukrainian people in the exercise of their property rights contribute only to ensuring the ecological security of the country, the conservation of natural resources for the benefit of present and future generations of citizens of Ukraine, the people as a whole, as well as addressing all issues related to possession and disposal these resources are under your direct control and direct involvement ${ }^{10}$. In other words, environmental and public-law interests are distinguished, which is indeed the case. But ownership, as a civil law category, has an economic component that mediates the material interest of the owner, which he can gain from owning, using and disposing of his property. Therefore, to the signs of the property rights of the Ukrainian people, offered by AO Pervomaiskyi, namely: the absolute nature of the property right of the Ukrainian people; the immutability of his subject; invariance of its contents; impossibility of termination or restriction by any laws ${ }^{11}$ should be added such features that would characterize the property of the Ukrainian people as a civil legal category. Such features should be: the material interest of the owner, that is, the Ukrainian people, in obtaining material benefits and the civil legal representation of the state and territorial communities towards the Ukrainian people, acting on behalf and in the interests of the Ukrainian people.

The legal status of objects that by their very nature should only be owned by the Ukrainian people should be spelled out at the legislative level.

Thus, it is expedient to consolidate at the legislative level the concept of property rights of the Ukrainian people in the civil law aspect, not through Article 324 of the Civil Code of Ukraine, but through the conceptual apparatus of civil legal instruments, which includes precisely the specific features of the property rights of the Ukrainian people.

Therefore, the property right of the people of Ukraine is the exclusive right of the community of citizens of Ukraine of all nationalities to own, use and dispose of land, its subsoil, atmospheric air, water and other natural resources

${ }^{10}$ Перчеклій I.M. (2015) Право власності українського народу на природні ресурси: еколого-правові засади. Автореферат дисертації на здобуття наукового ступеня кандидата юридичних наук за спеціальністю 12.00.06 - земельне право; аграрне право; екологічне право; природоресурсне право. (рp. 11) Київ.; Калініченко З.Д. (2016) Питання законодавчого забезпечення права власності на природні ресурси./ Захист права власності Українського народу: вітчизняні реалії та зарубіжний досвід для України. Матеріали I Щорічної міжнародної науково-практичної конференції (22 вересня 2016 року). (р. 130). Київ: Національна академія прокуратури України.

${ }^{11}$ Спасибо-Фатєєва I.B. (Ed) Цивільний кодекс України: Науково-практичний коментар. Пояснення, тлумачення, рекомендації з використанням позицій вищих судових інстанцій, міністерства юстиції, науковців, фахівців (2011) Том. 5. (рp. 42). Харків: ФОП Лисяк Л.С. 
within the territory of Ukraine, the natural resources of its continental shelf, exclusive (marine) economic zone, as well as scientific achievements, national, cultural and historical values, including those located outside Ukraine, which are the property of Ukrainian property. whom people. Representation on the competences of the Ukrainian people as an owner on his behalf and in his interests shall be exercised by state authorities and local self-government bodies within the limits specified by the Constitution of Ukraine.

\section{Legislative improvement of the relationship between the ownership of the Ukrainian people on land and the right of private ownership of land by a natural person - a citizen of Ukraine}

In the previous section, we considered some aspects of the property rights of the Ukrainian people through the conceptual apparatus of civil legal instruments. As already noted, the Ukrainian people have the right to own, use and dispose of other natural resources of land, that is, the Ukrainian people have the right of ownership of natural resources, in particular land.

It should be determined that land, by virtue of its properties and peculiarities of existence, is an object that can not be considered only in the plane of one legal concept or legal science. Land is a unique object of legal regulation, the national wealth of Ukraine. Therefore, first, and this is very important, the land in the understanding of the territory in the constitutional-legal aspect, is in essence one of the features of the state under constitutional law, that is, the land performs the most important function - the state-forming. But it should be emphasized that the Constitution of Ukraine introduces the concept of ownership of the Ukrainian people, that is, it operates with civil legal instruments, which becomes so decisive at the level with the constitutional feature of the land as the territory of the state. Thus, secondly, land is an object of civil law as a property with a special status to which the property of the Ukrainian people applies. Third, land becomes an object of agricultural law as an instrument of production without which any agricultural production is impossible; fourth, environmental law views land as a natural resource subject to state protection and protection against the negative impact of the environment. And so recently there is a debate among scientists that the legal status of the land has a social component. Its underestimation had a negative impact on the use of social levers of influence in establishing and implementing sustainable development ${ }^{12}$.

In this context, V. Golovchenko notes that the earth as a geographical category is the basis of the environment, all other natural objects and living creatures cannot exist outside its boundaries. In this sense, the earth's

\footnotetext{
12 Лібанова Е.М. (Еd) Соціально-економічний потенціал сталого розвитку України та іï районів (2014) Національна доповідь. ( pp. 108) Київ : ДУ “ІЕПСР НАН України”.
} 
biopotential has no other analogues and cannot be estimated in any monetary equivalent. Derivatives of the generic term "land" are other terms ("land resources", "land", "land relations", "land code", "land law", etc.).

Therefore, the question of the objective potential of the so-called land market / circulation in Ukraine, in particular, of agricultural land, becomes very urgent. According to statistics in Ukraine, agricultural land is almost 72 percent. This is a large part of the territory of the state. Moreover, these lands have high fertility, and thus potentially have high economic attractiveness.

To date, land relations in Ukraine are governed by such basic legislative acts as the Constitution of Ukraine, the Land Code of Ukraine, the Law of Ukraine "On the procedure for allocating in-kind (on the ground) land plots to owners of land parcels (shares)" regarding the use of unallocated and unclaimed land plots and land shares (units) dated June 5, 2003, as amended; .The Law of Ukraine "On Amendments to Certain Legislative Acts of Ukraine Concerning the Issue of Collective Land Ownership, Improvement of Land Use Rules in Agricultural Lands, Prevention of Raiding and Encouragement of Irrigation in Ukraine" of July 10, 2018 and others.

All of these pieces of legislation are intended to regulate land relations, but they appear to be even more confusing.

An indicator of this was the question of the present time regarding the opening of the market / circulation of agricultural land, which, as noted, constitutes more than $2 / 3$ of the total area of the state of Ukraine. Can the state freely dispose of the property of the Ukrainian people as its representative without the corresponding powers conferred on the state by the people. In the context of this issue, it is first and foremost necessary to link the tools of the various fields of law, since this question can be solved by using the methods of public law, including constitutional law. This will allow the people to express their opinion in the All-Ukrainian Referendum, since only such will of the people can be considered as legitimate granting of special powers to the state as a representative of the Ukrainian people. Thus, such representation of the interests of the state in relation to the Ukrainian people in matters of ownership will orient the state to fulfill its duties as a representative of the Ukrainian people in the civil legal plane. In due time, it was emphasized by O.M. Borshchevskaya, which determined the need to combine public-legal and private-legal principles of legal regulation of the property rights of the Ukrainian people ${ }^{14}$.

13 Головченко В. Земля: майно чи ресурс? Retrieved from http://yur-gazeta.com/ publications/practice/zemelne-agrarne-pravo/zemlya-mayno-chi-resurs-.html

14 Борщевська O.M. (2017), Нестеренко А.C. (Еd) Поєднання публічно-правових і приватноравових засад правового регулювання здійснення права власності українського народу. Процесс модернізації системи державного управління: конституційний, 
As it is rightly defined in the Constitutional submission on the official interpretation of the provisions of the first sentence of part one of part 13, part one of Article 14 of the Constitution of Ukraine in a systematic connection with the provisions of first part of the Preamble, provisions of Article 1, part two of Article 3, part two of Article 5, part 4 Article 13 of the Constitution of Ukraine in the Constitution (Articles 13, 14, 142) the concept of "land" is used in several meanings, namely as: the object of property rights of the Ukrainian people; object of property rights of citizens, legal entities and the state; the property of territorial communities. And given that land appears in different meanings given its versatile characteristics and purpose, there is a need to interpret the concept of land as an object of the property rights of the Ukrainian people and the main wealth under special protection of the state ${ }^{15}$.

Concerning the question of ownership of land of an individual, it can be noted that the ownership of land is acquired in several ways. As under civil law agreements (Article 131 of the Land Code of Ukraine), but it should be noted immediately that there is still a moratorium on the sale of agricultural land. And from birth every Ukrainian is guaranteed the right to free privatization of land. According to Article 121 of the Land Code ${ }^{16}$, citizens of Ukraine have the right to transfer land free of charge in the following sizes:

1) for farming in the size of the average land share (share) which is defined as the average of the village council or district (from 1.1 hectares in Ivano-Frankivsk region to 8.8 hectares in Lugansk region, on average across Ukraine -4 hectares );

2) for keeping a private peasant farm - no more than 2.0 hectares;

3) for gardening - no more than 12 acres;

4) for construction, maintenance of dwellings, outbuildings in villages up to 25 hectares, in settlements - not more than 15 hectares, in cities - not more than 10 hectares;

5) for individual cottage construction - no more than 10 acres;

6) for construction of individual garages - no more than 1 hectare.

Members of hostilities, including members of the ATO, in accordance with paragraph 14 of Article 12 of the Law of Ukraine "On the status of war

адміністративний та фінансовий аспекти: колективна монографія (рp.33-51). Одеса: Видавничий дім "Гельветика"

${ }^{15}$ Конституційне подання депутатів щодо офіційного тлумачення положень першого речення частини першої частини 13, частини першої статті 14 Конституції України у системному зв'язку із положеннями речення першого Преамбули, положень статті 1 , частини другої статті 3, частини другої статті 5, частини 4 статті 13 Конституції України. Retrieved from http://ccu.gov.ua/sites/default/files/3_6992.pdf

16 Земельний кодекс України (25.10.2001) Retrieved from https://zakon.rada.gov.ua/ laws/show/2768-14 
veterans, guarantees of their social protection" of October $22,1993^{17}$ have the right to a privilege - first of all land for individual housing construction, gardening and horticulture.

A citizen of Ukraine has the right to privatize six hectares of land during his lifetime. However, it is not enough to have the right, it is necessary to realize it also, having started registration of the land plot in the property.

And here is the question. Someone has land on the right of permanent use (for housing, personal or household shares, etc.), and someone is not able to exercise their right due to the lack of land territory relative to the population of Ukrainian citizens.

The legitimate dilemma arises whether or not such a rule of law is "dead"as that which does not have its own mechanism of legal regulation.

First of all, it should be noted that the fundamental principle of both constitutional law and civil law is the de jure equality of all citizens before the law. In fact, we get the opposite - inequality and injustice. Civil law tools should be used to avoid such distortions of the law. This concerns, first and foremost, the potential property right of an individual - a citizen of Ukraine for free privatization and the correlation of such right with the ownership of the Ukrainian people in this case on land. This can be interpreted as follows every citizen of Ukraine is a potential owner of a land plot, an area that is directly proportional to the number of citizens of Ukraine at a certain point in time and at the same time is a collective owner of land as a natural resource within the Ukrainian people. But the land resource is not infinite, and the number of citizens of Ukraine is constantly increasing. Therefore, the legal norm for free privatization of 6 hectares of land for different purposes for each citizen cannot be fulfilled for objective reasons.

The simplest but not legal measure would be to exclude such a rule from the legislation of Ukraine, but this would violate the principle of justice, which is a priority in the implementation of legal rules. Because, someone was able to exercise his right, and another citizen for the above reasons could not exercise that right. But the legal solution to this situation is through compensation. To do this, it is necessary to amend the Land Code of Ukraine, namely to supplement Article 121 of the Land Code of Ukraine with part 4 of the following content: destination - a citizen of Ukraine at the age of 18 has the right to apply to the relevant executive authority or local self-government body, which transfers land to the state or property ownership in accordance with the powers defined in Article 122 of the Code requesting compensation for the market value of the land on which he was entitled to free privatization.

${ }^{17}$ Про статус ветеранів війни, гарантії їх соціального захисту. (22.10. 1993) Закон України. Retrieved from https://zakon.rada.gov.ua/laws/show/3551-12 
Thus, any citizen of Ukraine would have the opportunity to defend their right to free privatization - or through substantive legal protection, having obtained a land plot in kind in the manner of privatization. Or because of a legal defense of such a right. This would also have a certain effect on the social protection of Ukrainian citizens.

It is clear that the legal mechanism for the implementation of this rule of law in by-laws should be described in the future. However, this would solve the gap in the legislation on the impossibility due to the lack of land plots to realize the right of every citizen of Ukraine to free privatization of land plots for a certain purpose.

Logically, another question arises. How does private ownership of land as an object of civil and land law relate to the ownership of the Ukrainian people on land as a natural resource. It should be noted that the common concept of natural resources is their definition as objects and systems of living and nonliving nature, components of the natural environment that surround the person, which are used in the process of social production to meet the material and cultural needs of man and society and ensure their livelihood. Therefore, the Ukrainian people as the owner of land resources have a special legal status in relation to the natural person - the owner of the land. Such relations can be deduced through Article 110 of the Land Code of Ukraine "The concept of restriction in the use of land plots, encumbrance of land rights". But first we need to consider what is the restriction and encumbrance of land rights.

According to Art. 2 of the Law of Ukraine "On the State Central History of True to Own Property and Their Restriction" 18 is a prohibition to perform and / or join its own property, which is established or established by law, or is usually used in the relevant public service which deals with strong responsibilities. contracts. Note that until recently, the concepts of "delay" and "restriction" have been used by different parts that have differently, very, in fact, defined the same jurisprudence. After the adoption of the Law of Ukraine "On the Transition to the Law of Ukraine" Centralized Real Rights to Real Estate Property and Their Violations Existed "and Other Legislative Acts of Ukraine dated 11.02.2010 No. 1878-VI. In such circumstances, the restoration of true truth to real estate is created as temporary or arbitrary additional necessary owners of enemies who decorate certain surveys when performing Orthodoxy from known own property. The truths obtained were not used by the various proprietors, but in the reduction of their orthodox persons, members and industries are impossible property or parts thereof. In your property, the property owner cannot adhere to the real anomaly of real property on his own property.

18 Про державну реєстрацію речових прав на нерухоме майно та їх обтяжень. (01.07.2004). Закон України року Retrieved from https://zakon.rada.gov.ua/laws/show/1952-15 
But these changes are not included in Articles 110, 111 and other Land Code of Ukraine. Due to this, the collective reliability of the legal ideal idea operates. We have 111 Land Code of Ukraine "Expansion of the true on the land plot, reduction in the internal land plot" does not remain a clear demarcation of what you need to have. But this, as used, is a false practice, but it is impossible to prevent the Ukrainian people from treating the right of an individual landowner to the deterioration of the land unity, its ministry, and to change its target value. As for the natural resource, the land should be a family and use it for a purposeful solution. Such unbounded reliability has diminished and it is observed that their organization is represented at the legal level, which made it possible to actually realize the ownership of the Ukrainian population on land in sufficient quantity. Thus, one can see the real truth about land as represented by the owner of land plots that protect the rights of the Ukrainian people on land as a natural resource. With profitable ownership of the land, the person should be that the land has a special natural resource, national wealth, which is within the Constitution of Ukraine and there is a mandatory ownership of the Ukrainian population on the land, the Ukrainian people support the right to survey the property rights of any - what kind of person on the land. Finding that land, like other natural resources, is a special object of law that exists as a national wealth, then the ownership of the land as a true civilian cannot be known that can be used in any case, as is the case with other objects. Therefore, the restriction of ownership should be taken into account as the owner of his own land uses his rights of the land owner to the extent that does not send the rights of people who should be excluded from the owners of their own land, which should be attributed to the rights of other persons to be determined. necessarily Orthodox. by a court decision. Such right can also be seen as the right of third parties (when, Article 659 of the Civil Code of Ukraine).

For this purpose the following amendments and additions to the legislative acts of Ukraine should be made:

1) Article 110 of the Land Code of Ukraine should be read in the following wording:

Article 110. Concept of Restriction in Use of Land Plots, Burden of Rights to Land Plot

"1. Restrictions may be imposed on the use of the land owner or part thereof.

The ownership of the land is burdened with the ownership of the Ukrainian people.

2. The transfer of ownership of land does not terminate the established restrictions, encumbrances. 
3. The division or consolidation of land does not terminate the encumbrance of the property of the Ukrainian people.

4. The division or consolidation of land shall not terminate the restrictions imposed on the land, except where the encumbrance extends only to a part of the land which, as a result of the division of the land, did not enter into the new land formed.

2) Article 111 of the Land Code of Ukraine should be read in the following wording:

Article 111. Burdening of rights to land, restrictions on land use:

1. The encumbrance of rights to land is established by the Constitution of Ukraine and other legislative acts as the property right of the Ukrainian people to natural resources. The owner of the land plot is forbidden to influence the deterioration of the fertility of the agricultural land plot, to harm the purpose of the land plot, to change the purpose of the land plot.

2. The law, adopted in accordance with it normative legal acts, contract, court decision may set the following restrictions on land use:

a) condition to start and finish building or development of the land plot within the set terms;

b) prohibition of conducting certain activities;

c) prohibition on changing the purpose of the land plot, landscape;

d) condition for the construction, repair or maintenance of the road, road section;

e) the condition of compliance with environmental requirements or performance of certain works;

e) conditions to grant the right to hunt, to catch fish, to collect wild plants on their land plot in due time and in due course;

(e) the obligation to maintain and preserve forest protective strips.

g) other

3. Burdening of rights to land does not require State registration as it is a constitutional right of the Ukrainian people and protected by law at the level of the Constitution of Ukraine.

4. Restrictions on the use of land (except for restrictions directly established by law and regulations adopted in accordance with them) shall be subject to state registration in the State Land Cadastre in accordance with the procedure established by law and shall be effective from the moment of state registration.

Restrictions on the use of land, directly established by laws and regulations adopted in accordance with them, shall be valid from the moment of entry into force of the legal acts which they were established.

5. Information on land use restrictions shall be specified in land management schemes and feasibility studies on the use and protection of land 
of administrative-territorial units, land management projects on the organization and establishment of boundaries of territories of nature reserve fund and other nature conservation, recreational, recreational, cultural and recreational purposes, forestry, land of water fund and water protection zones, restrictions on the use of land and their regime-forming objects, land use projects, providing ecological and economic assessment of crop rotation and ordering land, land management projects on land allocation, technical documentation land management on the establishment (renewal) boundaries of the land in kind (on location). Information on such restrictions shall be added to the State Land Cadastre.

3) To supplement Article 140 "Grounds for termination of ownership of land property" of the Land Code of Ukraine with the following points:

g) change of purpose of the land plot;

h) damage to the intended purpose of the land plot;

i) deterioration of the fertility of agricultural land or damage to other land.

4) In the Law of Ukraine "On State Registration of Property Rights to Real Estate and their encumbrances" the concept of "encumbrance" should be changed to "restriction" in order to harmonize legislative material with the Land Code of Ukraine and to rationally protect the ownership of the Ukrainian people on land.

\section{Problems of opening the market / land circulation in the aspect of exercising the right of ownership of land by the Ukrainian people and the right of private ownership of land by a natural person - a citizen of Ukraine}

At the present stage of the development of statehood in Ukraine, the question of market opening / land circulation in the state becomes urgent. This issue is rather acute in terms of the underdevelopment of the legislative framework. At present, this issue is becoming not only a legal one, but it is becoming a political one.

It is generally accepted that land, as a natural resource, has no value, but it has value because it is a national asset, as stated in the Constitution of Ukraine. This apartment can have both value and value. Therefore, we are not talking about the land market, but about its turnover.

Each state works for the development and growth of the economy, the increase of jobs, but it cannot be said that this will lead to the opening of the possibility of free sale of land by lifting the moratorium. This statement is false.

Land turnover is not an end in itself. The opening of free circulation of land should be the result of the reform, which will pass the stages of creating 
appropriate effective and transparent mechanisms for encouraging peasants to conduct agriculture, identify the priority of agricultural business. The mechanisms for granting preferential credits, tax breaks, demonopolizing the market and other incentives for the agricultural producer must first be earned and tested. And only if a positive economic result from the introduction of such innovative principles can be said about the possibility of lifting the moratorium on the burdens arising from the ownership of the Ukrainian people on land as a natural resource.

It should be noted that some steps are being taken in this direction by the Government of the country. The Bill "On Amendments to Certain Legislative Acts of Ukraine Regarding Conditions of Circulation of Agricultural Lands" 19 was prepared, but as of January 14, 2020, it did not pass the second reading in the Verkhovna Rada of Ukraine because it does not correspond to the realities of today and does not protect the rights of agricultural producers.

The Law of Ukraine "On Amendments to Certain Legislative Acts of Ukraine on Resolving the Issue of Collective Land Ownership, Improving Land Use Rules in Agricultural Land, Preventing Raiding and Promoting Irrigation in Ukraine in 2018" which came into force on January $1,2019^{20}$.

This Law has completely revised Article 13 of the Law of Ukraine "On the Procedure for Allocating Land (Units) in Land (Units) to Owners of Land Shares (Units)" of June 5, $2003^{21}$, which deals with the use of unallocated and unclaimed land and shares (Units). The law defines and demarcates the concepts of unallocated land and unclaimed land.

An unallocated land plot is a land plot, which according to the project of land management for the organization of the territory of land parcels (shares) was included in the area of land to be distributed, but in accordance with the protocol on the allocation of land plots was not allocated to the owner of the land share (share).

Unclaimed is a land share (share) for which no document confirming the right to it has been received, or a land share (share) entitled to it in accordance with the law, but which has not been allocated in kind (on the ground).

19 Про внесення змін до деяких законодавчих актів України щодо умов обігу земель сільськогосподарського призначення. (03.01.2020). Законопроект до другого читання. Retrieved from http://w1.c1.rada.gov.ua/pls/zweb2/webproc4_1?pf3511=66948

${ }^{20}$ Про внесення змін до деяких законодавчих актів України щодо вирішення питання колективної власності на землю, удосконалення правил землекористування у масивах земель сільськогосподарського призначення, запобігання рейдерству та стимулювання зрошення в Україні. (10.07.2018). Закон України. Retrieved from https://zakon.rada.gov.ua/ laws/show/2498-19

${ }^{21}$ Про порядок виділення в натурі (на місцевості) земельних ділянок власникам земельних часток (паїв). (05.06.2003). Закон України. Retrieved from https://zakon.rada.gov.ua/laws/show/ 899-15 
It is regulated that unallocated land plots, unclaimed shares (shares) after their formation into land plots by the decision of the respective village, settlement, city council may be leased for the purpose intended for the term up to the day of state registration of the ownership of such land plot, which is indicated in the lease of the land plot, and the owners of the land parcels (shares) or their heirs, who did not take part in the land plot allocation, are informed about the results of the land division conducted parcels in writing registered letter with an inventory and return receipt or by delivery of a notification in person, knowing their location.

The deadline for registration of the ownership right of the owner (his heir) of the unclaimed land share (share) is also set in case if by 1 January 2025 the owner of the unclaimed land share (share) or his heir did not register the ownership of the land, he is considered to have refused from the receipt of land. And under the norms of civil law, such unclaimed land share (share) after its formation in the land plot by the decision of the respective village, settlement, city council (in case of need of formation) by the application of the relevant council on the basis of the court decision is transferred to the communal property of the territorial community in the territory of which it is located, in the order of recognition of the property as landless.

However, in case of missing the term for registration of the ownership of the land plot for good reason on the claim of the owner of the unclaimed land share (share) or his heir, the court may determine an additional term sufficient for such registration. In the absence of agricultural lands of collective ownership, such land share (share) may be allocated in kind (on the ground) at the expense of land of communal property of the respective territorial community (if such lands exist).

Within 7 years from the date of state registration of the communal property right to the land plot formed from the unclaimed land share (share), it is prohibited to transfer it to private property (except for the transfer to the owner of the unclaimed land share (share) or his heirs).

Such a law would be considered a breakthrough and a step towards moving the land reform forward, but the following should be considered.

First, as already mentioned, it is possible to obtain land of no more than 6 hectares for all types of purpose for free privatization of land. Such a right may already be exercised by a person, and the land share may exceed that size. The Law and any other normative act do not prescribe the legal mechanism of settlement and monetary relations regarding the transfer of such land shares (shares) to the owner or his heirs. Therefore, it is logical to assume that such an excess amount of land area (share) that was not included in free privatization can be obtained only for money. 
According to statistics, it should be noted that the World Bank Director for Ukraine, Belarus and Moldova, Satu Kahkonen, stated that the poverty rate in Ukraine has increased by 10 percent over the past five years and that 25 percent of the population is below the poverty line ${ }^{22}$. Therefore, the question arises whether the owner of the land (shares) or his heir at market price can issue the ownership right to it, especially since the limit of such actions expires on January 1, 2025.

Currently, there is no mechanism in the state to obtain cheap targeted loans to obtain funds for the registration of ownership of their land shares (units). And to a greater degree of injustice in the Law it is determined that if the owner has not exercised such a right within a specified period, then it is considered that he has relinquished his land share (share) and such property is recognized as homeless and transferred to communal property. The legislator assumes that a person for the next 7 years, that is, until January 1, 2032, will be able to find the funds to execute the ownership right, so he imposes a restriction of 7 years from the date of state registration of the communal ownership of the land plot to transfer it into private ownership to another person, except transfer to the previous owners of such unclaimed land (share) or his heirs. But the law does not prohibit the transfer of such land for rent to other persons with all its consequences, such as the right of priority purchase of leased property (Article 777 of the Civil Code of Ukraine).

Thus, the new wording of Article 13 of the Law of Ukraine "On the Procedure for Allocating Land (Units) in Land (Units) to Owners of Land Shares (Units)" of 5 June 2003 may in essence become an instrument that will allow for the removal of land (shares) by their owners. for objective reasons, they will not be able to draw up properly. And property rights will be violated by law. But this cannot be allowed in the rule of law.

It should also be noted that in view of the current jurisprudence it is impossible to count on obtaining ownership of a land plot (share) in accordance with Article 119 of the Land Code of Ukraine due to statute of limitations. Thus, the Supreme Court of Ukraine, having analyzed Article 119 of the Land Code of Ukraine, stated that this rule gives grounds to conclude that for citizens who conscientiously, openly and continuously use the land plot for 15 years, but do not have documents proving their rights there are no advantages to this land, since even observance of all conditions of limitation does not lead to the emergence of ownership of the land and actually sends to the general order of the provision of land in property or use (Articles 118, 123 of the Land Code of Ukraine). This provision provides only the right to apply

\footnotetext{
22 Економічна правда. (11.10.2018) Retrieved from https://www.epravda.com.ua/ publications/2018/10/11/641524/
} 
to a public authority or local self-government with a request for the transfer of a land plot to property or use and does not provide for the mandatory transfer of a land plot to the property or use of such persons, in accordance with the procedure prescribed by law and the submission of necessary documents ${ }^{23}$.

That is, if you wish to acquire ownership of a land plot that is in communal or state ownership, it is in principle indifferent that a person has used it openly and in good faith for 15 years or more. One way or another, the person should apply to the local self-government body or public authority and to acquire the ownership of the land within the limits of the free transfer of land determined by Article 121 of the Land Code of Ukraine in accordance with the procedure established by the Land Code of Ukraine. In doing so, the competent authority may refuse to acquire the right of the applicant on the grounds provided for by the Land Code of Ukraine despite the open and fair use of the land plot for more than 15 years.

In view of this, it is possible to propose to the legislator, to regulate at the legislative level the position that if a citizen does not have objective possibilities for registration of the ownership of the land (share) he received legally, then it cannot be restricted in this right by specific terms. Such land (share) must remain with the citizen in permanent use with all the rights arising therefrom and the possibility for him or his heirs to register the ownership of it in accordance with the law without any time limit. That is the idea that should be the basis for the amendment of Article 13 of the Law of Ukraine "On the Procedure for Allocating Land to Owners of Land Shares (Units) in kind (on the ground)"of 5 June 2003.

General ideas on land reform should also be outlined, in terms of opening up land circulation in Ukraine, which need to be finalized by the legislature to prevent abuse in this area. Here it should be remembered that land is not a commodity. A commodity is what a person's work is attached to. Therefore, some scientists believe that they are not selling land but the right to use the land. Therefore, it is more appropriate not to talk about the land market, but about its turnover. These are conceptual concepts that will need to be substantiated in the discussion process.

It should be borne in mind, as already stated above, that land has a stateforming function and therefore it should belong only to the citizens of Ukraine and no ephemeral investments from foreign countries can be an excuse for opening land circulation to them. Land resources are the property of the Ukrainian people and therefore the fate of the land turnover should be decided only on the initiative of the people in the All-Ukrainian referendum on the correct questions, not through sociological polls.

23 Постанова Верховного Суду України. Касаційного цивільного суду, справа № 742/2916/15-ц (11.04.2018). Retrieved from http://reyestr.court.gov.ua/Review/73627618 
In view of the above, the circulation of agricultural land may be opened with the possibility of obtaining agricultural land for ownership only to persons of Ukraine who permanently reside in Ukraine in rural areas at the place of regional registration and intend to use it for their intended purpose (as noted, non-compliance of this requirement for targeted use of land will be the basis according to the amendments to Article 140 of the Land Code of Ukraine termination of ownership of such land and removing it from the face).

The thesis that deserves attention is M.V. Shulga, who notes that it should be borne in mind that today some citizens of western Ukraine have obtained the citizenship of neighboring states, while retaining the citizenship of Ukraine. Residents of Donetsk and Lugansk regions have the decree of the President of the Russian Federation to obtain the citizenship of the Russian Federation in a simplified manner. Finally, Ukraine's willingness to grant citizenship to ethnic Ukrainians without giving up citizenship of another country should also be taken into account. The combination of the above factors can create a situation that can cause the danger of loss of territorial integrity of our state. This cannot be allowed, since territorial integrity ensures the independence of any state ${ }^{24}$.

Therefore, it is reasonable to take into account the idea that in the case of land reform, if a citizen of Ukraine moves to a permanent residence in another country or if he becomes a bipatrid (a person with dual citizenship, which by the way is currently prohibited for citizens of Ukraine), the land becomes communal property territorial community or state property with potential compensation to the person for its value. Then such land can be legally transferred to another agricultural producer from among the citizens of Ukraine.

Before opening the free circulation of agricultural land, it is necessary to adopt a number of legal acts that would allow peasants who wish to obtain ownership of the land (share) to have the most favorable financial conditions for it - loans, installments, preferential holidays, etc.

The state and local self-government bodies should have control over the functions of land use for its intended purpose without interfering with the economic activities of agricultural producers.

There should be a reasonable restriction on the allocation of land to property, which will be deducted from the profitability formula of farming in a particular locality in the production, processing and sale of agricultural products - giving preference to small and medium-sized farms.

${ }^{24}$ Шульга М.В, Устименко В.А. (Еd) (2019) Землі як об’єкт земельних відносин: матеріали Всеукраїнської науково-практичної конференції (29 листопада 2019 р., м. Київ). Об'єкти екологічного і суміжних галузей права: теоретичні та практичні аспекти в умовах сталого розвитку. (рp. 67) Київ: НАН України. Ін-т економіко-правових досліджень. 


\section{CONCLUSIONS}

The research on the legal aspects of regulating the ownership of the Ukrainian people on land in the light of the reform of land relations in Ukraine and the results obtained on it are aimed at solving a scientific problem, consisting in the development of new theoretical and applied provisions on the protection and property rights of the Ukrainian people and its implementation within the framework of land reform in Ukraine. It should be noted that some issues have only been flagged as they require more sophisticated elaboration on in-depth case study.

In particular, the study formulates the following main conclusions:

1. The ownership of the Ukrainian people on land as a natural resource is an integral, guaranteed by the Constitution of Ukraine and must be taken into account in land relations in the process of land reform.

2. To take into account the will of the Ukrainian people solely through holding an All-Ukrainian referendum, not through sociological polls.

3. The circulation of agricultural land may be opened with the possibility of obtaining land for ownership only to persons of Ukraine who permanently reside in Ukraine in rural areas at the place of regional registration and intend to use it for their intended purpose.

4. In case of departure of a citizen of Ukraine to a permanent place of residence in another state or if he becomes a bipatrid (a person with dual citizenship, which by the way is currently forbidden for citizens of Ukraine), the land becomes a communal property of the territorial community or state property with possible compensation to the person of it. cost. Then such land can be legally transferred to another agricultural producer from among the citizens of Ukraine.

5. Amend the legislation of Ukraine providing for the introduction of concepts of encumbrance and restriction, with a clear legislative definition. The notion of burdening the rights to land is a constant duty of the land owner to take into account the Ukrainian people's rights to land as a natural resource as a basis for differentiation of concepts. And the restriction of the property right should be defined as the obligation of the land owner to exercise his rights of the land owner within the limits that do not violate the rights of other persons, that is, the restriction of the rights of the land owner follows from the rights of another person, which are defined by normative legal acts, contract or court decision.

6. To supplement the list of grounds for termination of ownership of land in Article 140 of the Land Code of Ukraine by the following points:

g) change of purpose of the land plot;

h) damage to the intended purpose of the land plot; 
land.

i) deterioration of the fertility of agricultural land or damage to other

6. Improve Article 13 of the Law of Ukraine "On the Procedure for Allocating in Land (on the Territory) Land Plots to Owners of Land Shares (Units)"of June 5, 2003, by the provision that a citizen who has no objective possibilities for registration of ownership rights to the land (share) he received legally cannot be limited in this right by a specific timeframe. Such land (share) must remain with the citizen in permanent use with all the rights arising therefrom and the possibility for him or his heirs to register the ownership of it in accordance with the law without any time limit.

7. The state and local self-government bodies should have control over the functions of land use for its intended purpose without interfering with the economic activities of agricultural producers.

\section{SUMMARY}

The article deals with the problematic issues of exercising the property right of the Ukrainian people in light of the land reform announced by the Government of Ukraine in 2019. The urgency of the work is due to the fact that nowadays the whole Ukrainian people are facing the urgent issue of opening the market / circulation of land. However, very little attention is paid to the exercise and protection of land ownership for the Ukrainian people and not for individual citizens of Ukraine. Due to the peculiarity of the subject of such property right, there is a need for a thorough study and determination of the possibility for the present legal regulation of the exercise of the property rights of the Ukrainian people for natural resources, in particular land. The article identifies the property rights of the Ukrainian people, defines the concept of property rights of the Ukrainian people through the conceptual apparatus of civil legal instruments; Applied coverage of the problem of opening land circulation in the light of the exercise of land ownership by the Ukrainian people is provided in accordance with the existing legislative acts and proposed bills. It also offers suggestions for the rational and expedient exercise of its property right by the Ukrainian people through the social-legal component of such right.

\section{REFERENCES}

1. Конституція України прийнята на п'ятій сесії Верховної Ради України. (28.06.1996). URL: https://zakon.rada.gov.ua/laws/ show/254

2. Земельний кодекс України (25.10.2001) URL: https://zakon.rada.gov.ua/ laws/show/2768-14

3. Про статус ветеранів війни, гарантії їх соціального захисту. (22.10.1993) Закон України. URL: https://zakon.rada.gov.ua/laws/ show/3551-12 
4. Про порядок виділення в натурі (на місцевості) земельних ділянок власникам земельних часток (паїв). (05.06.2003). Закон України. URL: https://zakon.rada.gov.ua/laws/show/899-15

5. Про державну реєстрацію речових прав на нерухоме майно та їх обтяжень. (01.07.2004). Закон України року URL: https://zakon.rada.gov.ua/ laws/show/1952-15

6. Про внесення змін до деяких законодавчих актів України щодо вирішення питання колективної власності на землю, удосконалення правил землекористування у масивах земель сільськогосподарського призначення, запобігання рейдерству та стимулювання зрошення в Україні. (10.07.2018). Закон України. URL: https://zakon.rada.gov.ua/ laws/show/2498-19

7. Постанова Верховного Суду України. Касаційного цивільного суду, справа № 742/2916/15-ц (11.04.2018). URL: http://reyestr.court.gov.ua/ Review/73627618

8. Про внесення змін до деяких законодавчих актів України щодо умов обігу земель сільськогосподарського призначення. (03.01.2020). Законопроект до другого читання. URL: http://w1.c1.rada.gov.ua/ pls/zweb2/webproc4_1?pf3511=66948

9. Конституційне подання депутатів щодо офіційного тлумачення положень першого речення частини першої частини 13, частини першої статті 14 Конституції України у системному зв'язку із положеннями речення першого Преамбули, положень статті 1, частини другої статті 3 , частини другої статті 5, частини 4 статті 13 Конституції України. URL: http://ccu.gov.ua/sites/default/files/3_6992.pdf

10. Борщевська О.M. (2017), Нестеренко А.С. (Еd)Поєднання публічно-правових і приватноравових засад правового регулювання здійснення права власності українського народу. Процесс модернізації системи державного управління: конституційний, адміністративний та фінансовий аспекти: колективна монографія (pp. 33-51). Одеса: Видавничий дім "Гельветика".

11. Головченко В. Земля: майно чи ресурc? URL: http://yur-gazeta.com/ publications/practice/zemelne-agrarne-pravo/zemlya-mayno-chi-resurs-html

12. Дворкін Р. (2001) Серйозний погляд на права. (pp. 12). Київ : Основи.

13. Економічна правда. (11.10.2018) URL: https://www.epravda.com.ua/ publications/2018/10/11/641524/

14. Енциклопедія цивільного права України (2009). Ін-т держави i права ім. В.М. Корецького НАН України; відповід. ред. Я.М. Шевченко. (рp.664). Київ : Ін Юре. 
15. Калініченко 3.Д. (2016) Питання законодавчого забезпечення права власності на природні ресурси./ Захист права власності Українського народу: вітчизняні реалії та зарубіжний досвід для України. Матеріали I Щорічної міжнародної науково-практичної конференції (22 вересня 2016 року). (р. 130). Київ: Національна академія прокуратури України.

16. Комаров С.А. (1998) Общая теория государства и права. (pp. 81). Москва: Юрайт

17. Лібанова Е.M. (Ed) Соціально-економічний потенціал сталого розвитку України та іiі районів (2014) Національна доповідь. (рp. 108) Київ:ДУ “ІЕПСР НАН України”.

18. Орзіх М.П. (1995) Концепція правового статусу самоврядних територій і органів місцевого самоврядування. Місцеве та регіональне самоврядування України, № 1, 67.

19. Перчеклій I.M. (2015) Право власності українського народу на природні ресурси: еколого-правові засади. Автореферат дисертації на здобуття наукового ступеня кандидата юридичних наук за спеціальністю 12.00.06 - земельне право; аграрне право; екологічне право; природоресурсне право. (рp. 11) Київ.;

20. Скакун О.Ф. (2001) Теорія держави і права. (рp. 39) - Харків: Консум

21. Спасибо-Фатєєва I.B. (Ed) Цивільний кодекс України: Науковопрактичний коментар. Пояснення, тлумачення, рекомендації 3 використанням позицій вищих судових інстанцій, міністерства юстиції, науковців, фахівців (2011) Том. 5. (рр. 42). Харків: ФОП Лисяк Л.С.

22. Шульга М.В, Устименко В.А. (2019) Землі як об’єкт земельних відносин: матеріали Всеукраїнської науково-практичної конференції (29 листопада 2019 р., м. Київ). Об’єкти екологічного і суміжних галузей права: теоретичні та практичні аспекти в умовах сталого розвитку. (pp. 67) Київ: НАН України. Ін-т економіко-правових досліджень.

\section{Information about the author:} Olena Borschevska, $\mathrm{PhD}$, Associate Professor at the Department of Civil and Labor Law, Odessa National Maritime University 34, Mechnikov str., Odessa, 65029, Ukraine ORCID ID: orcid.org/0000-0003-2549-429X 